\title{
KARAKTERISTIK KEPEMIMPINAN: Transformasional versus Transaksional
}

\author{
I Made Narsa \\ Fakultas Ekonomi dan Bisnis, Universitas Airlangga, Surabaya, Indonesia \\ Email:narsa_ua@yahoo.com
}

\begin{abstract}
Abstrak
Paper ini bertujuan menelaah secara deskriptif mengenai manajemen vs. kepemimpinan, dan atau manajer vs. leader, dilihat dari sudut karakteristik utama pada keduanya. Hasil telaah menunjukkan bahwa ada karakteristik yang tegas yang membedakan antara manajemen dan kepemimpinan, dan antara manajer dan leader. Esensinya adalah manajemen merupakan fungsi yang berkenaan dengan mengerjakan sesuatu dengan benar atas dasar transaksional. Sementara kepemimpinan merupakan panggilan dan kualitas diri yang berkenaan dengan mengerjakan sesuatu yang benar atas dasar transformasional.
\end{abstract}

Kata Kunci: Kepemimpinan, Manajer, Leader, Transaksional, Transformasional.

\begin{abstract}
This paper was intended to review descriptively about management vs leadership, and/or manager vs leader in term of their main characteristic. The review result showed that there were strickly differences between management and leadership and between manager and leader. Essentialy, management was a function that concerned with doing this right on a transactional based, meanwhile leadership was call and self quality that concerned with doing the right thing on transformational based.
\end{abstract}

Keywords: Leadership, Manager, Leader, Transactional, Transformational.

\section{PENDAHULUAN}

Perdebatan mengenai komponen organisasional yang menjadi penggerak bagi kemajuan (atau kemunduran) sebuah organisasi selalu menempatkan kepemimpinan sebagai titik perhatian. Konteks ini sangat nalar karena kepemimpinan merupakan salah satu komponen terpenting atau inti (Marquardt, 1996) di antara komponen-komponen lain organisasi seperti struktur, budaya, praktik manajerial, misi, visi, tujuan dan strategi, kebijakan dan prosedur, serta iklim kerja.

Dalam memahami konsep kepemimpinan, perlu memahami beberapa hal. Menurut Maxwell (1998) ada beberapa perbedaan di antara manajemen dan kepemimpinan, yaitu (a) manajemen berbeda dengan kepemimpinan. Kepemimpinan adalah kegiatan memengaruhi orang lain untuk ikut, sedangkan manajemen terfokus pada pemeliharaan sistem dan proses. (b) Wirausahawan tidak memerlukan kepemimpinan meskipun wirausahawan memiliki kemampuan persuasif, namun acapkali bebas dan kurang memengaruhi orang lain seperti pemimpin. (c) Pemimpin biasanya bukan orang yang paling banyak tahu dalam organisasi. (d) Kepemimpinan harus dipahami sebagai bukan posisi atau jabatan yang dipegang, melainkan sebagai kemampuan memengaruhi orang lain.

Kotter (1996) mengatakan kepemimpinanlah yang melahirkan visi dan strategi, sedangkan manajemen menurutnya melahirkan rencana, yaitu langkah-langkah spesifik dan jadwal untuk mengimplementasikan strategi, dan anggaran yaitu rencana yang diterjemahkan dalam proyeksi dan sasaransasaran keuanga. Stephen Covey menyitir pernyataan Bennis dan Drucker yang menyatakan bahwa "management is concerned with doing this right" sedangkan "Leadership is concerned with doing the right thing" (Covey, 1989). Memahami dan mendalami masalah kepemimpinan mungkin sangat membingungkan. Meindl et al. (1985) mengatakan "The concept of leadership remains largely elusive and enigmatic," dan kepemimpinan masih sangat ambigu baik dalam definisi maupun pengukuran (Pfeffer, 1977)

Variasi definisi mengenai kepemimpinan dinyatakan dengan tegas oleh Yukl (1989) bahwa, "The term leadership means different things to different people." Yukl (1989) juga mengutif dari tujuh penulis mengenai definisi leadership, satu diantaranya adalah dari Jacobs (1970), yang mendefinisikan, 'Leadership is an interaction between persons in which one 
presents information of a short and in such a manner that the other becomes convinced that this outcomes...will be improved if he behaves in the manner suggested or desired" (Yukl, 1989) Robbins (1997) mendefinisikan "leadership is the notion that leaders are individuals who, by their actions, facilitate the movement of a group of people toward a common or share goals". Ini berarti kepemimpinan merupakan sebuah proses untuk memengaruhi orang lain atau unit organisasi untuk mencapai tujuannya. Disamping itu, inti kepemimpinan sebenarnya adalah melakukan hal yang benar. Pemimpin harus dapat menggerakkan, memuaskan dan menumbuhkan pengikut yaitu motivasi dan "menghidupkan" potensinya, juga harus mampu menangani paradoks-paradoks dan menjelaskan maknanya.

Kontroversi mengenai isu-isu kepemimpinan merupakan suatu fenomena yang sangat jelas. Beberapa teoritisi percaya bahwa kepemimpinan tidak berbeda dari proses memengaruhi sosial yang terjadi diantara semua anggota kelompok, dan kepemimpinan dipandang sebagai proses kolektif dari seluruh anggota kelompok. Tetapi pandangan lain melihat bahwa semua kelompok memiliki spesialisasi peran yang di dalamnya mencakup spesialisasi peran kepemimpinan (Yukl, 1989). Stogdill (1974) sebagaimana dikutip oleh Yukl menyimpulkan "Leadership has been defined in terms of individuals trait, leader behavior, interaction patterns, role relationships, follower perceptions, influence over followers, influence on task goals, and influence on organizational culture" (Yukl, 1989).

Dalam konteks manajemen dan kepemimpinan, mungkin sekali terjadi kondisi yang mana seorang pemimpin yang baik, namun merupakan manajer yang buruk sehingga perlu dilengkapi oleh seorang manajer yang baik di dalam teamnya. Sebaliknya seorang pimpinan yang buruk namun memiliki kemampuan manajerial yang baik sehingga belum tentu diikuti oleh orang lain di organisasinya. Tanpa adanya saling melengkapi, seorang yang kepemimpinannya lemah akan menghasilkan stagnasi, sedangkan seorang yang manajemennya lemah akan menghasilkan konsep saja atau wacana tanpa kelancaran aplikasinya. Eisenbach et al. (1999) mengkaji keterkaitan kepemimpinan, gaya manajemen, dan perubahan organisasi, dan mengatakan bahwa "... change management depends on leadership...".

Isu lainnya adalah menyangkut transaksional dan transformasional. Berbagai bentuk hubungan dan implikasi dari kepemimpinan transaksional dan transformasional sudah banyak diteliti secara empiris, misalnya oleh Al-Mailam (2004) yang meneliti tentang apakah karyawan yang bekerja di bawah kepemimpinan transformasional merasa pemimpin mereka lebih efektif dibandingkan dengan karyawan yang bekerja bagi pemimpin transaksional. Bono \& Judge (2004) meneliti hubungan antara personalitas dan kepemimpinan dan delapan dimensi dari kepemimpinan transaksional dan transformasional. Judge \& Piccolo (2004) menguji tentang validitas kepemimpinan transaksional dan kepemimpinan transformasional. Sementara Deluga (1990) menguji secara eksperimental hubungan (a) empat karakteristik kepemimpinan (charisma, inspiration, intellectual stimulation, dan individual consideration); (b) dua karakteristik kepemimpinan transaksional (contingent reward dan management-by-exception); dan (c) kepemimpinan laissez faire dengan perilaku memengaruhi bawahan secara halus, keras dan rasional. Singer \& Singer (1989) menguji kendalakendala situasional atas perilaku transformasional dan transaksional, preferensi subordinat, dan kepuasan.

Dari pengamatan subjektif penulis pribadi terhadap kepemimpinan di Indonesia, penulis menyimpulkan terdapat fenomena yang sangat khas. Sebagaimana teori-teori lainnya, jika diuji di Indonesia hasilnya adalah anomali, atau bergeser dari konsep dasarnya. Teori keagenan misalnya yang thesis dasarnya menjelaskan konflik hubungan antara prinsipal-agen sulit diuji di Indonesia, karena tidak jelas siapa prinsipal dan siapa agen. Akhirnya teori keagenan dipergunakan untuk menjelaskan hubungan dua pihak yang berkonflik yang bukan lagi prinsipalagen, boleh jadi konflik antar prinsipal itu sendiri, yaitu prinsipal mayoritas dan prinsipal minoritas.

Pucuk-pucuk pimpinan dalam organisasi di Indonesia, baik organisasi bisnis privat, organisasi publik, yayasan, bahkan organisasi sosial kemasyarakatan (bisa juga organisasi sosial keagamaan), lebih banyak muncul karena political power. Si Polan menjadi CEO PT. A dalam usia muda, karena perusahaan itu milik keluarganya (meskipun sudah publik). Si Dullah menjadi Dirut dalam sebuah BUMN, karena ditempatkan oleh Partai $\mathrm{X}$ yang punya power. Si Jamil menjadi ketua organisasi sosial kemasyarakatan karena dibentuk oleh Partai Y sebagai organisasi underbow. Si Komo menjadi ketua organisasi sosial keagamaan melalui pemunggutan suara yang 'panas' karena juga diharapkan dapat membawa anggotanya menjadi pendukung sebuah partai Z. Jika demikian, sulit menjelaskan apakah mereka adalah leader yang memiliki jiwa kepemimpinan? Boleh jadi mereka itu adalah leader, atau sekedar manajer yang punya power karena posisi, atau politik.

Pengamatan penulis terhadap fenomena lainnya juga menarik. Misalnya, di dalam suatu organisasi 
yang bersifat nir laba, semestinya kepemimpinan yang ditumbuhkan adalah kepemimpinan transformasional. Namun, karena seringnya terjadi pemimpin dipilih bukan berdasarkan track-record atau riwayat kinerjanya, melainkan berdasarkan konsensus sosial, maka pemimpin-pemimpin formal acapkali bukan merupakan orang yang bermodalkan karakter, kompetensi dan komitmen yang tinggi. Akibatnya mereka berusaha mati-matian untuk bertahan pada kedudukan mereka.

Berdasarkan fenomena yang teramati dan hasilhasil riset empiris yang telah dilakukan, timbul pertanyaan apakah manajemen dan kepemimpinan merupakan dua hal yang berbeda atau terpisah? Apakah seorang manajer adalah seorang pemimpin? Apakah manajer lebih berperilaku transaksional sementara leader lebih berperilaku transformasional?

Paper ini bertujuan menelaah dan menganalisis secara preskriptif-deskriptif untuk membedakan secara tegas antara manajemen dan kepemimpinan dari dua dimensi yang disebutkan terakhir, yaitu transaksional dan transformasional. Kontribusi tulisan ini, paling tidak memberikan 'penyadaran' dan landasan teoritis untuk menentukan secara jelas mana manajer yang leadership dan mana yang bukan, atau mana manajer transaksional dan mana manajer transformasional. Rerangka teoritis ini penting sebagai acuan jika dilakukan penelitian mengenai kepemimpinan khususnya di Indonesia.

\section{PEMBAHASAN}

Sebelum membahas konsep pemimpin dan kepemimpinan, pertanyaan berikut dapat dijadikan bahan perenungan, yaitu orang yang seperti apa yang bisa dikatakan sebagai pemimpin, dan apakah jika seseorang mampu menggerakkan orang lain dengan serta merta kita sebut sebagai pemimpin?

Pemimpin-pemimpin sejati menggerakkan diri orang lain selain dirinya. Mereka mencipta keadaan, suasana dan semangat. Kita merasakan impian kita bertumbuh dan dipertajam. Pemimpin-pemimpin itu membuat potensi atau hal-hal yang terbaik dari diri kita muncul ke permukaan. Dalam bahasa yang lebih ilmiah, kita menyebutkan bahwa seorang pemimpin merumuskan visi bersama, menggerakkan orang bersamanya dan menghasilkan transformasi.

Tiga hal penting yang dapat membuat seseorang dapat menggerakkan orang lain, yaitu karena Ia: (a) Diberi kepercayaan oleh banyak pihak, terutama dari mereka yang mengikutinya. Smircich \& Morgan (1982) dalam tulisannya yang berjudul Leadership: The Management of Meaning, menyatakan "... leadership involves a dependency relationship in which individuals surrender their power to interpret and define reality to others..." (italic penekanan dari penulis). Pemimpin sejati harus mendapatkan kepercayaan dari pengikutnya. Tanpa kepercayaaan itu mereka bukanlah pemimpin dan akan gagal total. (b) Mau menerima kepercayaan atau power yang diberikan. Acapkali, orang yang diberikan "kepercayaan" tidak terlalu berminat. Ia mencari berbagai alasan untuk tidak menerima "kepercayaan" tersebut. Ia telah menyadari beratnya tantangan yang akan dihadapi. Namun perlu dicatat bahwa tidak semua orang punya pembawaan lahir (trait) untuk menjadi seorang pemimpin. Memang hal ini bisa diperdebatkan, berdasarkan paradigma trait dan behavior (House \& Aditya, 1997). Namun ada esensi penting yang bisa ditangkap, yaitu "kepercayaan" dari orang lain atau pengikut. (c) Mau memberikan kepercayaan kepada orang lain, bahwa Ia akan terus belajar. Mendapatkan kepercayaan dari orang banyak, pengikut atau atasan, berarti ada sejumlah pengalaman, pengetahuan, keterampilan (skill), dana dan jejaring yang diberikan oleh mereka. Bila Ia mendapatkan kepercayaan dari orang berarti Ia mendapatkan tanggung jawab dan sekaligus komitmen dari orang lain. Seorang pemimpin harus bersedia diperiksa intergritasnya secara terus menerus, dan secara terus menerus memelihara kualitas karakter dan tingkat kinerja yang tinggi.

Mengapa suatu kepercayaan dari orang banyak dapat diperoleh atau diberikan kepada seseorang? Karena, (a) Ia telah menampilkan pengabdian. Artinya, ia cenderung mendahulukan kepentingan komunitasnya daripada kehendak dirinya. Ia rela mengorbankan dirinya demi visi bersama yang diidamkannya. (b) Ia memiliki keunggulan-keunggulan. Biasanya kita cenderung mengikuti orang yang dipandang lebih unggul dari diri kita. Keunggulankeunggulan tadi mencakup kemampuannya memimpin diri sendiri, kemampuan memimpin hubungan antar pribadi, dan kemampuan menangani pekerjaan atau kegiatan-kegiatan komunitasnya atau pelayanan organisasinya. Lord et al. (1986) menemukan ada tiga trait — intelegensi, dominasi, dan maskulinitas - yang berhubungan secara signifikan dengan persepsi pengikut terhadap kepemimpinan. (c) Ia handal dalam memberikan inspirasi dan menggali makna hidup atau makna keberadaan komunitas atau organisasinya. Karena keyakinan atas makna itu, mereka menjadikan dirinya sumber inspirasi bagi orang-orang di sekitar diri mereka. Epitropaki (2003) mengatakan "... leaders who are usually responsible for communicating this meaning (as well as vision, mission and values) are also likely to play a vital role in inspiring employees to connect their self identity with that of the 
organization". Bagi mereka, hidup bukan hanya rangkaian kegiatan untuk memenuhi kebutuhankebutuhan hidup yang tidak habis-habisnya. Hidup adalah suatu perjalanan menuju sasaran tertentu, pendakian menuju puncak tertentu, serta mencari dan mengkomunikasikan makna.

\section{Kepemimpinan Transformasional atau Transak- sional}

Satu dari sekian banyak teori-teori kepemimpinan komprehensif mengenai transformasi organisasional adalah teori kepemimpinan transformasional dan teori kepemimpinan transaksional. Teori ini diperkenalkan oleh Burns (1978) dalam konteks politik, kemudian dikembangkan dan diperhalus oleh Bass (1985) dalam konteks organisasional.

Teori Kepemimpinan Transformasional juga mengakui pentingnya power dan proses memengaruhi (influence processes). Hubungan Pemimpinpengikut dipandang sebagai satu intensi emosi yang mana pengikut memberikan kepercayaan dan keyakinan yang besar kepada Pemimpin (Bass et al., 1987; Burns, 1978). Bass (1985) menyebutnya karisma, inspirasi, pertimbangan (consideration) individual, dan stimulasi intelektual sebagai empat karakteristik yang membentuk kepemimpinan transformasional.

Karisma diartikan sebagai "leader's perceived God-like qualities" yang menciptakan referent power dan influence (Bass, 1985). Inspirasi adalah kemampuan untuk menarik, mengajak dan secara emosional mengkomunikasikan idiealisme masa depan. Pemimpin memancarkan power dan memengaruhi pengikut melalui cara yang visioner. (Bass, 1985). Pertimbangan individual menggambarkan bagaimana pemimpin memperoleh power, baik melalui pelayanan maupun kepenasihatan dan pengembangan orientasi pengikut (Bass, 1985). Stimulasi intelektual mendorong pengikut untuk berpikir dengan cara baru terhadap masalah-masalah lama (think of old problems in new ways), mendorong mereka mempertanyakan nilai-nilai dan keyakinan yang dimilikinya dan apakah sesuai dengan pemimpinnya (Bass et al., 1987).

Teori Kepemimpinan Transformasional menyatakan bahwa pemimpin dapat mengoptimalkan power dan pengaruh mereka terutama melalui karisma (referent power), inspirasi (visionary processes). Pengikut boleh jadi tidak sekedar menganggap bahwa

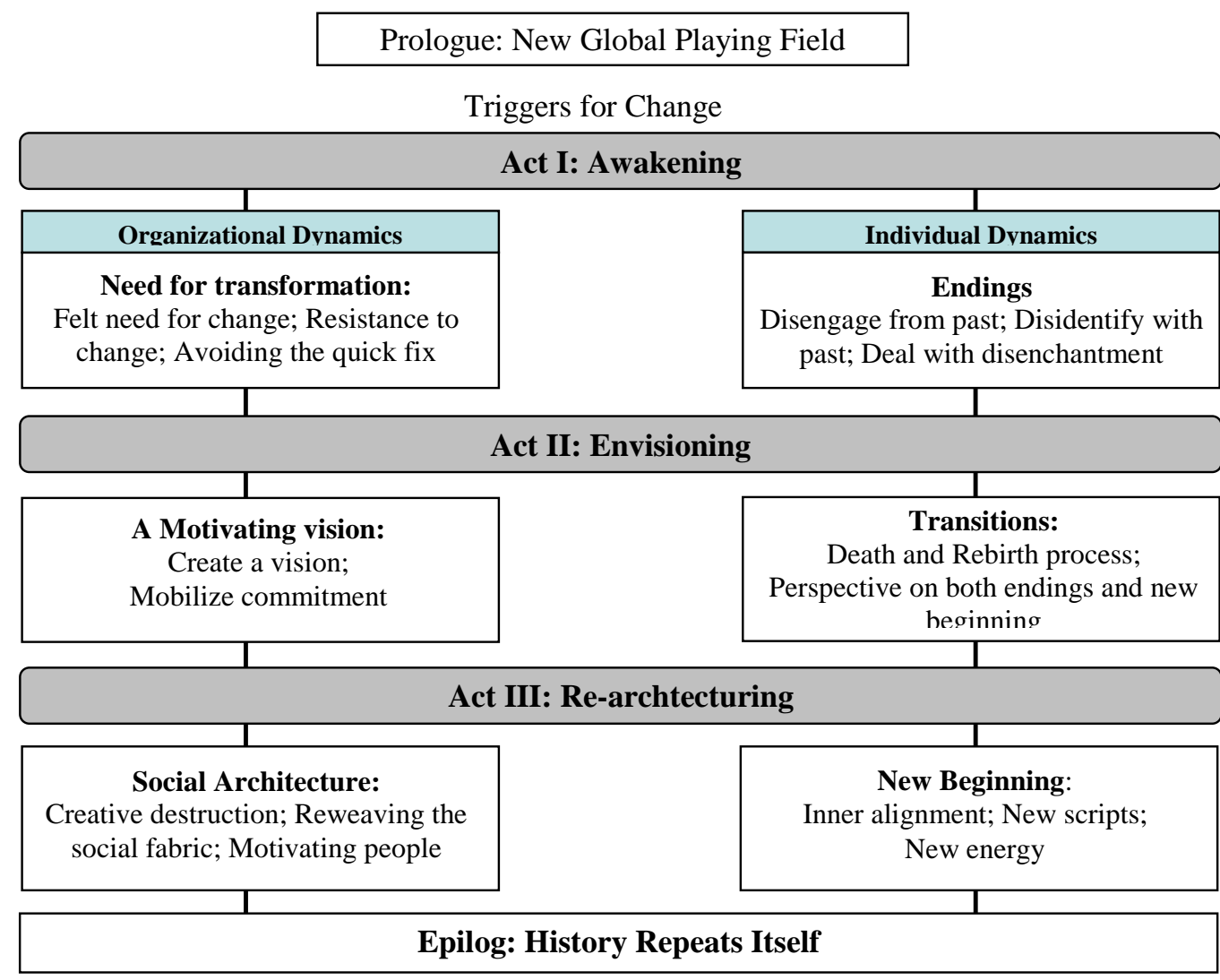

Sumber: Tichy dan Sherman dalam (Mintzberg et al., 1998)

Gambar 1. Transformational Leadership: A Three-Act Drama 
pemimpin hanyalah simbol. Aspek-aspek pemodelan peran dari pertimbangan individual dan motivasi kognitif dipicu atau boleh jadi dimoderasi oleh stimulasi intelektual.

Pertanyaannya adalah, bagaimana transformasi itu terjadi? Menurut Tichy dan Sherman (1993) sebagaimana dikutip oleh Mintzberg et al. (1998) transformasi itu terjadi melalui drama tiga babak ( $a$ three-act drama), yaitu: Awakening, Envisioning, dan Rearchitecturing. Proses transformasi drama tiga babak ini dapat digambarkan pada Gambar 1.

Pemimpin transfirmasional adalah pencipta dan pembangun sebuah "fajar" yang baru dalam kehidupan sebuah organisasi (Ruky, 1997).Meskipun banyak variasi mengenai definisi kepemimpinan transformasional, secara umum dapat didefinisikan sebagai "agen perubahan". Eisenbach et al. (1999) mengatakan "... to carry out the pertinent change process". Perannya yang utama adalah sebagai katalis bagi perubahan yang akan dilaksanakan tetapi tidak pernah bertindak sebagai "pengawas".

Masalah yang lebih penting bagi seorang pemimpin transformasional adalah selalu mempunyai visi yang kuat, sebuah gambaran tentang bentuk organisasinya di masa depan bila semua tujuan-tujuan utamanya telah dicapai (Covey, 1989). Dengan demikian, seorang pemimpin transformasional juga haruslah seorang yang visioner (Chandra, 1997; Huseini, 1997). Esensi kepemimpinan serupa ini adalah mampu menghasilkan perubahan yang mana dirinya dan mereka yang terkait dengannya samasama mengalami perubahan ke arah yang lebih luas, lebih tinggi, dan lebih mendalam. Kata kunci dari segenap keputusannya adalah seberapa jauh sebanyak mungkin pihak mengalami pertumbuhan.

Penelitian tentang penerapan kepemimpinan transformasional di berbagai budaya (Boehnke et al., 2003), menemukan bahwa semua pemimpin transformasional memiliki kesamaan perilaku: visioning, yaitu memberikan rumusan masa depan yang diinginkan; inspiring, yaitu menimbulkan kegairahan; stimulating, yaitu menimbulkan minat untuk hal baru; coaching, yaitu memberikan bimbingan satu persatu; dan team building, yaitu bekerja melalui kelompok kerja.

Bagaimana dengan kepemimpinan transaksional? Berbasis pada social learning theory (Bandura, 1977) dan social exchange theory (Hollander, 1979), teori kepemimpinan transaksional mengakui adanya sifat leadership dengan hubungan deterministik timbal balik (reciprocal) (Bass, 1985; Burns, 1978; Hollander, 1978; Tichy \& Devanna, 1986). Pemimpin dan bawahan dipandang sebagai agen-agen yang membuat kesepakatan, dan mengatur kekuatan- kekuatan relatif dalam sebuah proses pertukaran yang saling menguntungkan. Bass (1985) menyatakan ada dua karakteristik yang membentuk kepemimpinan transaksional, yaitu (a) contingent reward yang menggambarkan bahwa sistem pembayaran sudah lazim dipakai sebagai aransemen untuk memengaruhi, yang mana ada kesepakatan secara eksplisit atau implisit atas tujuan yang akan dicapai dalam rangka untuk mendapatkan reward yang diinginkan. (b) management-by-exception, yang dicirikan bagaimana pemimpin memonitor penyimpangan negative yang dilakukan oleh bawahan dan mengambil tindakan koreksi hanya jika bawahan gagal untuk mencapai tujuan yang ditetapkan.

Teori Kepemimpinan Transaksional menyatakan, bahwa leader dan/atau bawahan dapat saling melaksanakan power dan pengaruh, yang dilaksanakan dalam suatu proses pertukaran yang saling menguntungkan. Sebagai contoh, seorang leader memiliki informasi vital (Pettigrew, 1972) atau di pihak lain seorang bawahan memiliki keahlian khusus dalam memecahkan masalah-masalah penting organisasional (Mechanic, 1962), kondisi ini mendorong keduabelah pihak untuk bernegosiasi yang saling menguntungkan, jadi ada transaksi di antara mereka.

Pemimpin transaksional adalah pemimpin yang selalu "bertransaksi" dengan bawahan. Jika ia memberi, apa yang ia dapatkan, atau jika ia memerintah, ada sesuatu yang ia janjikan. Misalnya, Ia mengatakan "Jika gaji kalian ingin dinaikkan, maka naikkan dulu produktivitas kalian"

Seorang pemimpin, apalagi yang dikenal dengan pemimpin formal sebagai lawan dari pemimpin informal dapat terjebak untuk menjadi pemimpin transaksional. Pemimpin yang bersifat transaksional menghubungkan diri dengan orang-orang yang dipimpinnya, atasannya, serta dirinya sebagai pemainpemain dalam suatu proses transaksi. Ia ini lebih cocok disebut sebagai seorang manajer yang selalu berusaha melakukan pekerjaan dan fungsinya dengan benar (do things right). Ciri khas seorang pemimpin transaksional adalah hubungannya dengan bawahan didasarkan pada azas mutually beneficial (Ruky, 1997).

Bahkan, ada yang berpikir untuk lebih menguntungkan dirinya sendiri. Keputusan yang diambilnya merupakan keputusan yang menguntungkan baginya dalam hubungan dirinya dengan berbagai pihak. Masalah benar atau salahnya keputusan tadi tidak jadi perhatian utamanya, namun masalah untung atau rugi terutama bagi kepentingannya sering menjadi dasar pertimbangan.

Kepemimpinan transaksional cenderung tidak membuat organisasinya atau pihak-pihak yang terkait 
dengannya berkembang apalagi orang-orang yang dipimpinnya. Kecenderungannya ialah memanfaatkan berbagai pihak bagi dirinya.

\section{Manager versus Pemimpin}

Acapkali orang tidak membedakan antara pemimpin dan manajer. Seorang manager adalah seorang yang mengelola sesuatu. Hal yang ia kelola adalah manusia, waktu, mesin, dana atau informasi serta jejaring. Jadi ukuran keberhasilannya adalah seberapa baik ia berfungsi dalam mengelola apa yang dipercayakan kepadanya.

Sebaliknya, seorang pemimpin adalah seorang yang melakukan sesuatu demi organisasi, kelompok, atau komunitasnya. Ia diukur berdasarkan pada apa yang dihasilkannya bersama mereka yang mengikutinya atau yang terkait dengannya. Ia juga diukur dengan transformasi yang dilakukannya, serta adanya kelanjutan dari pekerjaannya. Dalam proses memimpin pengikutnya, seorang pemimpin tidak harus selalu rapi, teratur, atau indah dengan rencana yang matang dan budget, namun yang terpenting adalah bahwa ia melakukan hal-hal yang benar untuk kepentingan bersama sesuai dengan panggilan hati nuraninya yang mencerminkan kualitas diri seseorang.

Berikut adalah cuplikan sebuah peristiwa sebagai contoh ilustratif untuk memeroleh pemahaman mengenai manajer dan pemimpin:

"Pada suatu hari Minggu, Seorang ayah dan keluarganya sedang berada di sebuah mall yang baru saja dibuka di Surabaya. Karena membutuhkan uang tunai Dia berusaha mencari ATM, kemudian bertanya kepada seorang petugas berseragam di mall. "Pak ATMnya di mana?". Dengan tanpa melihat si penanya orang itu memeriksa peta mall, dan berkata, "Lantai dua mas." Setelah berkeliling di lantai dua sang ayah tidak menemukan ATM itu, dan Dia kembali. "Pak kok gak ada?" Ia menoleh dan bertanya pada teman di sebelahnya "Oh, di lantai dasar mas, tapi belum semuanya fungsi" Hal itu dikatakannya dengan ekspresi wajah yang datar-datar saja".

Dari sekelumit "kisah sedih" di hari Minggu itu, bisa dilihat bahwa petugas tadi adalah seorang pengelola informasi, namun bukan seorang pemimpin yang dapat menimbulkan kegairahan pada siapapun yang ia temukan. Ia pun melanjutkan hari-harinya tanpa suatu visi atau keperdulian pada orang lain.

\section{SIMPULAN DAN SARAN}

Dari uraian sebelumnya dapat ditarik beberapa buah simpulan, yaitu bahwa: manajemen adalah fungsi yang mana hubungan dengan bawahan berdasarkan otoritas dengan tujuan menghasilkan sesuatu, serta melibatkan hal-hal yang lebih rutin. Proses transaksi menjadi bagian penting dalam hubungan antara manajer dan bawahan. Seorang manajer adalah orang yang melakukan hal yang dipercayakan kepadanya dengan benar (managers do things right). Dengan demikian, manajer lebih bersifat mekanistis (orientasi semata-mata pada memenuhi suatu ukuran keberhasilan yang ditetapkan baginya) dan menekankan pada pengendalian kerja bawahan.

Kepemimpinan adalah panggilan atau kualitas diri, yang mana hubungan dengan pengikut berdasarkan pengaruh, dengan tujuan memberikan arah dalam tindakan dan sikap, serta melibatkan visi dan penilaian. Pemimpin memiliki kepekaan terhadap arah, kerja sama kelompok, inspirasi, teladan dan penerimaan diri oleh orang lain. Jadi pemimpin melakukan hal yang benar (Leaders do the right thing) sesuai visi sebagai sehingga terjadi transformasi bersama.

Dalam kenyataan, acapkali dituntut bahwa seorang pemimpin harus juga menjadi seorang manajer. Tentunya, yang ideal adalah didapatkan seorang pemimpin yang baik dan sekaligus berfungsi menjadi manajer yang baik. Manajemen dengan leadership tinggi, untuk mendorong terjadinya transaksi yang saling menguntungkan, sekaligus membawa transformasi untuk mencapai visi bersama.

Implikasinya adalah pada tataran yang paling awal, ketika dilakukan rekruitmen dalam sebuah organisasi perlu dipikirkan strategi yang tepat sehingga diperoleh calon-calon leader yang memiliki leadership tinggi. Calon yang direkrut adalah yang memiliki atitude baik, sementara keterampilan bisa dilatih dan dikembangkan (recrutiment for attitude, skill is trained). Dengan demikian, orang yang berprestasi akademik tinggi boleh jadi bukan merupakan calon terbaik untuk menjadi transformational leader.

\section{DAFTAR REFERENSI}

Al-Mailam, F.F. 2004. Transactional Versus Transformational Style of Leadership-Employee Perception of Leadership Efficacy in Public and Private Hospitals in Kuwait. Q Manage Health Care, 13(4): 278 - 284.

Bandura, A. 1977. Social Learning Theory. Englewood Cliffs, NJ: Prentice-Hall.

Bass, B.M. 1985. Leadership and Performance beyond Expectations. New York: Free Press.

Bass, B.M., Waldman, D.A., Avolio, B.J., \& Bebb, M. 1987. Transformational Leadership and The Falling Dominoes Effect. Group \& Organization Studies, 12: 73-91. 
Boehnke, K., Bontis, N., \& DiStefano, J.J.A.C. 2003. Transformational Leadership: An Examination of Crossnational Differences and Similarities. Leadership Organization Development Journal, 24(1): $5-15$.

Bono, J.E., \& Judge, T.A. 2004. Personality and Transformational and Transactional Leadership: A Meta-Analysis. Journal of Applied Psychology, 89(5): 901-910.

Burns, J.M. 1978. Leadership. New York: Harper \& Row.

Chandra, A. 1997. Visionary Leadership: Gaya Kepemimpinan Untuk Organisasi Masa Depan. Usahawan, 09: 14.

Covey, S.P. 1989. The Seven Habits of Highly Effective People. $1^{\text {st }}$ Edition. New York: Somon \& Schuster.

Deluga, R.J. 1990. The Effects of Transformational, Transactional, and Laissez Faire Leadership Characteristics on Subordinate Influencing Behavior. Basic and Applied Social Psychology, 11 (2): 191 - 203.

Eisenbach, R., Watson, K. \& Pillai, R. 1999. Transformational Leadership in the Context of Organizational Change. Journal of Organizational Change Management, 12 (2): 80 - 88.

Epitropaki, O. 2003. Transformational Leadership, Psychological Contract Breach and Organizational Identifikaction. Academy of Management Best Conference Paper, OB: M1 - M6.

Hollander, E.P. 1978. Leadership Dynamics: A practical Guide to Effective Relationships. New York: Free Press.

Hollander, E.P. 1979. Leadership and Social Exchange Processes. In K. Gergen, M.S. Greenberg, \& R.H. Willis (Eds.), Group Process (pp. 103-118). New York: Winston-Wiley.

House, R.J., \& Aditya, R.N. 1997. The Social Scientific Study of Leadership: Quo Vadis? Journal of Management, 23(3): 409 - 473.

Huseini, M. 1997. Visionary Leadership dan Milenium Ke Tiga. Usahawan, 09: 15-17.

Judge, T.A., \& Piccolo, R.F. 2004. Transformational and Transactional Leadership: A Meta-Analytic Test of Their Relative Validity. Journal of Applied Psychology, 89(5): 755 - 768.

Kotter, J.P. 1996. Leading Change. Harvard Business School.
Lord, R.G., De Vader, C.L., \& Alliger, G.M. 1986. A Meta Analysis of the Relation Between Personality Traits and Leadership Perceptions: An Application of Validity Generalizations Procedures. Journal of Applied Psychology, 71(3): 402 - 410.

Marquardt, M.J. 1996. Building The Learning Organization: A System Approach to Quantum Improvement and Global Success. USA: McGraw-Hill, Inc.

Maxwell, J.C. 1998. The Twentyone Irrefutable Laws of Leadership. Nashville, Tenn: Thomas Nelson Publishers.

Mechanic, D. 1962. Sources of power in Lower Participants in Complex Organizations. Admistrative Science Quarterly, 7: 349 - 336.

Meindl, J.R., Ehrlich, S.B., \& M.,D.J. 1985. The Romance of Leadership. Administrative Science Quarterly, 30: 78 - 102.

Mintzberg, H., Ahlstrand, B. \& Lampel, J. 1998. Strategy Safary: A Guided Tour Through Wilds of Strategic Management. New York: The Free Press.

Pettigrew, A.M. 1972. Information Control as A Power Resource. Sociology, 6: 187 - 204.

Pfeffer, J. 1977. The Ambiguity of Leadership. Academy of Management Review, 2 (1): 104 - 112.

Robbins, S.P. 1997. Managing Today. Upper Saddle River, New Jersey: Prentice-Hall International Inc.

Ruky, A.S. 1997. Penerapan 'Visionary Leadership' dalam Perusahaan Indonesia: Suatu "Conditio Sine Quanon" untuk Menyongsong Milenium Ketiga. Usahawan, 09: 7-8.

Singer, M.S., \& Singer, A.E. 1989. Situational Constraints on Transformational Versus Transactional Leadership Behavior, Subordinats' Leadership Preference and Satisfaction. The Journal of Social Psychology, 130(3): 385-396.

Smircich, L. \& Morgan, G. 1982. Leadership: The Management of Meaning. The Journal of Applied Behavioral Science, 18(3): 257-273.

Tichy, N.M. \& Devanna, M.A. 1986. The Transformational Leader. New York: Wiley.

Yukl, G. 1989. Managerial Leadership: A Review of Theory and Research. Journal of Management, 15(2): 251-289. 